\title{
Analisis Implementasi Peran Guru Dalam Penanaman Nilai Karakter Toleransi Pada Mata Pelajaran Pkn Di MI Ma'arif Darussalam Plaosan Yogyakarta
}

\author{
1Zaenuri, ${ }^{2}$ Siti Fatonah \\ 1,2 Universitas Islam Negeri Sunan Kalijaga Yogyakarta \\ *E-mail : 1urizae07@gmail.com,2Sitifat317@gmail.com
}

\begin{abstract}
Abstrak
Keberhasilan Pendidikan Kewarganegaraan bukan hanya sebatas mengetahui teori dalam buku namun juga adanya perubahan sikap yang ditunjukkan oleh siswa. Sikap toleransi ini perlu dikembangkan dalam dunia pendidikan. peneliti melakukan penelitian mengenai nilai karakter toleransi yang diterapkan melalui pembelajaran tematik pada mata pelajaran pendidikan kewarganegaraan. Dengan adanya pendidikan karakter toleransi dalam kegiatan pembelajaran ini maka peneliti berharap dengan tujuan bisa membentuk siswa yang bermoral, beretika, dan berkarakter, terutama bisa selalu toleransi baik dilingkungan sekolah maupun dilingkungan masyarakat. Jenis penelitian ini adalah kualitatif dengan menggunakan metode deskriptif yang ditujukan untuk mendeskripsikan tentang peran guru dalam penanaman nilai karakter toleransi pada mata pelajaran Pkn. Hasil dari penelitian ini menunjukkan bahwasanya MI Ma'arif Plaosan Darussalam Plaosan sudah menerapkan karakter toleransi, Adapun bentuk karakter toleransi yaitu, tidak menghina teman yang berbeda suku/ ras, selalu menghargai perbedaan pendapat teman,mentaati peraturan sekolah dan lain sebagainya. MI Ma'arif Plaosan peran guru dalam membimbing siswa dalam membimbing toleransi siswa yaitu, dengan mengarahkan siswa tentang bagaimana bisa bersikap toleransi yaitu dengan memberikan informasi apa saja dampak negatif. MI Ma'arif Plaosan dalam mengidentifikasi nilai karakter toleransi dengan memberikan materi Kebhinekaan dengan tujuan agar siswa mengetahui dan memaknai arti perbedaan. faktor pendukung dalam penerapan karakter toleransi di MI Ma'arif Darussalam Plaosan yaitu, sudah tersedianya fasilitas media pembelajaran seperti modul, buku untuk pembelajaran tentang materi toleransi yang terdapat dalam materi pembelajaran kewarganegaraan, kemudian faktor penghambatnya yaitu masih ditemukan anak yang daya tangkapnya berbeda, tentunya ini menjadi hambatan dalam membentuk karakter toleransi pada siswa, selanjutnya masih adanya kekurangan kesadaran siswa yang belum sepenuhnya melaksanakan karakter toleransi itu sendiri.
\end{abstract}

Kata kunci: Peran guru, Karakter toleransi, Pendidikan Kewarganegaraan

\begin{abstract}
The success of Citizenship Education is not only limited to knowing the theory in books but also the change in attitudes shown by students. This attitude of tolerance needs to be developed in the world of education. researchers conducted research on the value of the character of tolerance that was applied through thematic learning in civic education subjects. With the existence of tolerance character education in this learning activity, the researchers hope that with the aim of being able to form students who are moral, ethical, and have character, especially being able to always be tolerant both in the school environment and in the community. This type of research is qualitative using a descriptive method aimed at describing the teacher's role in inculcating the value of the character of tolerance in Civics subjects. The results of this study indicate that MI Ma'arif Plaosan Darussalam Plaosan has implemented the character of tolerance, the form of the character of tolerance is, not insulting friends of different ethnicity/racial, always respecting differences of opinion of friends, obeying school rules and so on. MI Ma'arif Plaosan the teacher's role in guiding students in guiding student tolerance, namely, by directing students about how to be tolerant, namely by providing information on what negative impacts. MI Ma'arif Plaosan in identifying the value of the character of tolerance by providing Diversity material with the aim that students know and interpret the meaning of differences. supporting factors in the application of tolerance character at MI Ma'arif Darussalam Plaosan, namely, the availability of learning media facilities such as modules, books for learning about tolerance material contained in civics learning materials, then the inhibiting factor is that children are still found with different grasping power, of course this is become an obstacle in forming the character of tolerance in students, then there is still a lack of awareness of students who have not fully implemented the character of tolerance itself.
\end{abstract}

Keywords: The role of the teacher, the character of tolerance, Citizenship Education 


\section{PENDAHULUAN}

Dalam kehidupan bermasyarakat, berbangsa dan bernegara diperlukannya peran penting dari pendidikan agar dapat berguna bagi peserta didik. Kemajuan suatu negara dilihat dari semakin baiknya pendidikan di negara tersebut. Hal ini dikarenakan proses pendidikan yang baik akan menghasilkan sumberdaya manusia yang berkualitas, sehingga dapat mengubah Negaranya menjadi lebih baik. Perkembangan kemampuan dapat bersifat kognitif, psikomotor, dan afektif sesuai dengan norma-norma yang ada dalam kehidupan masyarakat. Berkembangnya ketiga aspek tersebut sesuai dengan amanah tujuan demokratis Undang-Undang No. 20 Tahun 2003. D i dalam Pendidikan Kewarganegaraan telah dijadikan satu mata pelajaran yang berperan penting dalam meweujudkan warga yang unggul dan berkualitas (Ramadhaniar et al., 2020,1)

Standar isi satuan pendidikan dasar dan menengah yang dikeluarkan oleh Depdiknas menetapkan bahwa dalam mata pelajaran pendidikan kewarganegaraan adalah mata pelajaran yang menitikberatkan pada pembinaan pemahaman warga negara yang bertujuan agar para warga negara mampu melakukan apa yang menjadi hak dan kewajibannya sebagai warga negara Indonesia yang cerdas, terampil, dan bijaksana, serta memiliki sebuah ciri khas atau karakter yang sesuai dengan nilai-nilai Pancasila dan UUD 1945. Menurut Depdiknas dalam, Hardini, dijelaskan bahwa mata pelajaran pendidikan kewarganegaraan mempunyai tujuan untuk peserta didik yang diharapkan mampu untuk memiliki jiwa kaum intelektual yang bisa berpikir secara kritis serta rasional dan juga kreatif dalam menanggapi sebuah isu kewarganegaraan, (Pertiwi dkk. 2021, 4329).

Aktualisasi nilai dalam pembentukan karakter melalui dunia pendidikan memerlukan perencanaan yang teliti agar hasilnya sesuai dengan yang diharapkan. Proses penanaman nilai dalam pembentukan karakter melalui pendidikan harus dikemas secara baik dan berstruktur yang dapat diimplementasikan melalui kegiatan pembelajaran (Karmila dan Indriani 2019, 26). Berbicara mengenai pendidikan karakter tidak jauh berbeda dengan pembelajaran karakter. Pendidikan karakter menjadi sangat populer di zaman sekarang karena dalam kurikulum 2013 telah diterapkannya Penguatan Pendidikan Karakter (PPK). Lickona dalam Yaumi, menyatakan bahwa "character as knowing the good, desiring the good, and doing the good (mengetahui kebaikan, menginginkan kebaikan, dan melakukan segala sesuatu yang baik)"(Ariyanti et al., 2019, 44).

Pendidikan karakter saat ini merupakan topik yang marak diperbincangkan dalam dunia pendidikan. Pendidikan merupakan salah satu proses yang di dalamnya terdapat suatu aturan dan prosedur yang harus dimiliki oleh setiap peserta didik. Setipa peserta didik memiliki tanggung jawab yang sama dalam proses pembelajaran. Pendidikan menjadi pilar utama untuk memajukan generasi penerus bangsa demi perkembangan intelektual anak. Perkembangan intelektual tersebut nantinya akan membentuk kepribadian atau karakter anak. Merebaknya sikap hidup yang buruk dan budaya kekerasan atau merakyatnya bahasa ekonomi dan politik, disadari atau tidak, telah ikut melemahkan karakter anak-anak bangsa, sehingga menjadikan nilai-nilai luhur dan kearifan sikap hidup mati suri. Anak-anak sekarang gampang sekali melontarkan bahasa oral dan bahasa tubuh yang cenderung tereduksi oleh gaya ungkap yang kasar dan vulgar. Nilai-nilai etika dan estetika telah terbonsai dan terkerdilkan oleh gaya hidup instan dan konstan (Nurjanah, 2019, 13) 
Pendidikan kewarganegaraan merupakan salah satu proyek instruktif yang memiliki derajat yang luas dan mencakup tidak kurang dari tiga bidang dalam proses pembentukan pribadi, yaitu secara konseptual metroschooling berperan dalam menciptakan ide dan spekulasi, pelatihan kurikuler menumbuhkan berbagai proyekproyek instruktif, serta model implementasinya dalam mempersiapkan peserta didik menjadi warga negara yang dewasa berkarakter melalui landasan akademik, dan secara sosial. Dilihat dari hal ini bahwasanya Pkn cenderung dianggap sebagai penemuan yang sarat dengan nilai-nilai karakter, namun masalah yang didapat para ahli dilapangan bahwa praktik pembelajaran yang terjadi dikelas saat ini hanya terbatas pada sekolah yang berorientasi pada pencapaian tujuan intelektual ataupun informasi. Sementara emosional, hal-hal yang paling berhubungan dengan cara umum untuk membentuk kepribadian/ perspektif siswa pada umumnya akan diabaikan. Untuk itulah perlu adanya peningkatan pembelajaran Pkn dalam menciptakan peserta didik mulai dari menyusun, melaksanakan dan menilai. Kita harus mampu memiliki pilihan untuk melakukan penyususnan, pelaksanaan, dan penilaian yang dapat menyamarkan nilainilai orang yang ada karena pengembangan nilai karakter tidak cukup hanya diintruksikan melainkan juga harus diciptakan (Insani et al., n.d, 2021, 8154)

Guru dituntut untuk mampu membentuk atau mengembangkan katakter siswa. Keberhasilan Pendidikan Kewarganegaraan bukan hanya sebatas mengetahui teori dalam buku namun juga adanya perubahan sikap yang ditunjukkan oleh siswa. Sikap toleransi ini perlu dikembangkan dalam dunia pendidikan. Tidak ada jaminan, seorang siswa yang nilai ulangan Pendidikan Kewarganegaraan bagus sikap toleransinya bagus pula. Saat ini nilai-nilai ulangan yang bagus menunjukkan pengetahuan siswa mencapai nilai maksimal namun mungkinkah dengan nilai yang bagus siswa juga menerapkan sikap toleransi dengan baik (Ramadhaniar et al., 2020, 3).

Berdasarkan penelitian sebelumnya yang dilakukan oleh peneliti pada setiap kelas di SDN Kembangan Utara 05 Pagi, peneliti menemukan sikap kurangnya toleransi dikelas IV seperti siswa yang dikucilkan teman-temanya karena memiliki kelainan berkebutuhan khusus, memandang sebelah mata yang tidak seagama dan mengejeknya, kurang menghormati guru, saling mengolok-olok nama orang tua, bertengkar, berebut barang-barang, melakukan perundungan (bullying). Menurut peneliti, hal tersebut cocok untuk diteliti karena sekolah tersebut sudah menerapkan pembelajaran mengenai sikap toleransi sesama (Unggul \& Febrianti, n.d.2021, 3). Melihat fenomena tersebut, inilah yang disebut problem sikap toleransi. Sikap intoleransi harus segera di akhiri di Indonesia, terutama pada siswa sekolah dasar yang masih dalam fase pembentukan karakter. Dengan menanamkan sikap toleransi pada siswa sejak dari kecil maka akan ternanam karakter toleransi yang baik.

Berdasarkan hasil observasi bahwasanya penerapan pendidikan karakter pada saat proses pembelajaran berlangsung atau saat berada dilingkungan sekolah masih ada beberapa siswa yang masih belum mempunyai sikap toleransi sesama temanya sendiri, salah satu contohnya adalah tidak menghargai pendapat teman. Dari hal ini tentunya juga mempengaruhi pendidikan karakter yang terjadi pada anak tersebut. Namun juga sudah banyak siswa yang menerapkan sikap toleransi disekolah seperti selalu membantu teman saat mengalami kesulitan, tidak menghina teman yang berbeda ras ataupun kebiasaan, berteman dengan siapapun tanpa memandang status sosial dan lain sebagainya, hal ini adalah salah satu dampak dari proses pembelajaran Pkn yang sudah diajarkan oleh guru kepada peserta didiknya sehingga siswa/ siswi bisa menerapkanya dengan baik. Maka dari itu, peneliti ingin melakukan penelitian mengenai nilai karakter toleransi yang diterapkan melalui pembelajaran tematik pada mata pelajaran pendidikan kewarganegaraan. Dengan adanya pendidikan karakter toleransi dalam kegiatan pembelajaran ini maka peneliti berharap dengan tujuan bisa membentuk siswa 
yang bermoral, beretika, dan berkarakter, terutama bisa selalu toleransi baik dilingkungan sekolah maupun dilingkungan masyarakat.

\section{METODE PENELITIAN}

Jenis penelitian ini adalah kualitatif dengan menggunakan metode deskriptif yang ditujukan untuk mendeskripsikan tentang peran guru dalam penanaman nilai karakter toleransi pada mata pelajaran Pkn. Dalam buku Muh Fitrah dan Lutfiyah Penelitian kualitatif adalah suatu prosedur penelitian yang menggunakan data deskriptif berupa kata-kata tertulis atau lisan dari orang-orang dan pelaku yang dapat diamati. Kualitatif berarti sesuatu yang berkaitan dengan aspek kualitas, nilai atau makna yang terdapat dibalik fakta. Kualitas, nilai atau makna hanya dapat diungkapkan dan dijelaskan melalui linguistic, bahasa, atau kata-kata (Zaenuri \& Prastowo, 2021, 1738) .Penelitian yang dilakukan adalah penelitian kebijakan tentang pelaksanaan pendidikan karakter toleransi dalam buku tematik pada mata pelajaran Pkn. Subyek sekolah penelitian adalah MI Ma'arif Plaosan Yogyakarta yang berstatus Kurikulum 2013 yang menerapkan Pendidikan Karakter dalam Pembelajaran. Penelitian ini dimulai dari 12 November sampai dengan 20 November dengan menggunakan via whatapp/ wawancara tidak langsung.

Dalam memperoleh data penelitian, peneliti menggunakan dua sumber, yaitu data primer dan sekunder. Adapun sumber data primer yang digunakan oleh informan utama adalah guru kelas yang bertugas mengajar mata pelajaran Pkn. Sedangkan data sekunder yang digunakan meliputi jurnal dan buku. Teknik pengumpulan data yang digunakan adalah observasi, wawancara. Teknik analisis data menggunakan teknis analisis model interaktif (interactive model of analysis) dari Miles dan Huberman, yaitu reduksi data (data reduction), penyajian data (data display) dan penarikan kesimpulan (verification).

\section{HASIL DAN PEMBAHASAN \\ Karakter Toleransi}

Di MI Ma'arif Darussalam Plaosan, sikap toleransi telah diterapkan dalam pelaksanaan penanaman nilai karakter toleransi, beberapa contoh yang telah diterapkan yaitu selalu mengutamakan salam, tidak menghina teman yang berbeda ras/ kebiasaan, menghargai perbedaan pendapat antar teman tanpa memandang status sosial baik dalam diskusi belajar maupun di lingkungan sekitar, berbuat baik kepada semua orang tanpa kecuali, mentaati peraturan sekolah, dan tidak boleh membedabedakan suku dan agama saat berteman. Kemudian jenis sikap toleransi yang digunakan dalam pembelajaran nilai-nilai Pancasila, misalnya dengan menawarkan contoh-contoh nyata dari prinsip-prinsip Pancasila yang dapat dikaitkan dalam kehidupan sehari-hari. Tujuannya agar dapat membentuk kepribadian anak agar dapat berprestasi lebih baik, kemudian guna menghindari perpecahan, mmempererat hubungan manusia dan meningkatkan nasionalisme.

Toleransi adalah suatu sikap atau sifat dari seseorang untuk membiarkan kebebasan kepada orang lain serta memberikan kebenaran atas perbedaan tersebut sebagai pengakuan hak-hak asasi manusia ((Afifah, 2019; Christopher, 2019; Rahmawati \& Harmanto, 2020) . Nilai torelansi tidak hanya berlangsung dalam kegiatan pembelajaran PKn saja, namun harus diterampkan pada kehidupan sehari-hari. Selain penerapan nilai toleransi, implementasi pembelajaran PKn di sekolah dasar yang terintegrasi dalam pembelajaran tematik (Hasibuan, 2021) . Pembelajaran PKn yang aktif dan efektif dapat dikatakan baik apabila dalam pembelajaran juga didukung dengan bahan ajar yang memumpuni, juga menciptakan proses pembelajaran efektif 
guru perlu menggunakan bahan ajar seperti buku, media, dan metode pembelajaran (Puniatmaja dan Renda 2021, 410).

Berdasarkan keterangan diatas bahwasanya di MI Ma'arif Plaosan Darussalam Plaosan sudah menerapkan karakter toleransi, Adapun bentuk karakter toleransi yaitu, tidak menghina teman yang berbeda suku/ ras, selalu menghargai perbedaan pendapat teman,mentaati peraturan sekolah dan lain sebagainya yang bertujuan untuk membentuk kepribadian anak dan menjaga kekeluargaan satu sama lainya.

\section{Peran Guru Dalam Menanamkan Nilai Karakter Toleransi Siswa}

Di Mi Ma'arif Darussalam Plaosan bahwasanya Guru memiliki peran yang penting dalam penanaman karakter toleransi, karena anak-anak dapat mengetahui sikap tolerasi bukan hanya dari buku bacaan saja, guru juga harus menjadi teladan bagi siswa agar memiliki karakter yang baik terutama dalam bersikap (baik sikap sosialisasi \& religiusnya). Kemudian juga peran guru membuat aturan tata tertib untuk menekankan kepada siswa-siswinya agar selalu mengikuti peraturan yang sudah dibuat untuk diterapakanya, beberapa tata tertib yang ditanamkan yaitu 1) mematuhi tata tertib dan peraturan di sekolah, 2) tidak membeda-bedakan teman, 3) tidak mengejek atau berprilaku kasar pada teman 4) melakukan piket kelas sesuai jadwal, 5) tidak menggangu teman dan selalu menghormati guru. tidak membuat gaduh kelas kecuali ada hubungannya dengan pelajaranmemberi salam kepada guru tidak boleh meninggalkan kelas tanpa izin dari guru sopan santun terhadap guru dan teman.

Kemudian di MI Ma'arif Darussalam Plaosan ketika ada siswa-siswi yang melanggar aturan ataupun yang mentaati tata tertib yang sudah dibuat oleh guru maka akan ada hukuman ataupun penghargaan. Jika ada yang melanggar aturan misalkan tidak menghargai perbedaan pendapat teman/ ataupun mengejek sesame teman, maka hukumannya yaitu meminta maaf dengan ucapan yang baik kemudian berjabat tangan, dan akan ada pengurangan satu point. Reward yang diberikan untuk siswa yang mematuhi aturan yaitu akan mendapatkan tambahan nilai sepuluh point nilai sikap. Hukuman dan penghargaan. Selanjutnya jika siswa/ siswi sudah banyak sekali melanggar tata tertib ataupun sering intoleran terhadap sesame teman baik dari sisi apapun, maka tentunya aka ada panggilan orang tua wali murid untuk diberikanpengarahan.

Guru memiliki peran penting dalam bidang pendidikan. Berdasarkan Undang Undang RI Nomor 14 Tahun 2005 Bab 2 Pasal 4 Tentang Guru, seorang guru memiliki tugas, antara lain, guru sebagai pendidik, guru adalah seorang pendidik yang menjadi tokoh dan panutan bagi peserta didik dan lingkungannya, guru sebagai pelajar, guru bertugas untuk membantu peserta didik. Guru memiliki peran yang sangat penting dalam menanamkan nilai toleransi dengan mengintegrasikan pendidikan dengan berbagai budaya. Perilaku seorang guru di kelas menjadi kunci dalam membantu semua siswanya mencapai potensi tanpa memandang jenis kelamin, etnis, usia, agama, bahasa atau keistimewaan. Berikut adalah peran guru menurut Lickona, Schaps, Lewis dan Azra dalam dalam menanamkan nilai-nilai karakter salah satunya nilai toleransi antara lain, dalam usaha menanamkan karakter pada anak, pendidik harus terlibat secara langsung dalam proses baik kegiatan pembelajaran maupun kegiatan lainnya, pendidik atau guru bertanggung jawab menjadi contoh atau teladan yang memiliki nilai-nilai karakter termasuk nilai toleransi dan memberikan pengaruh kepada peserta didik. Guru harus dapat memberikan arahan kepada peserta didik bahwa karakter peserta didik tumbuh melalui kerjasama dalam mengambil keputusan, guru harus sering melakukan refleksi rutin mengenai masalah-masalah moral yang berkembang serta memastikan perkembangan karakter peserta didik secara berkelanjutan, Pendidik perlu 
menjelaskan dan mengklarifikasi kepada peserta didik secara berkesinambungan mengenai berbagai nilai-nilai yang baik maupun yang buruk (Pitaloka et al., 2021, 1701)

Berdasarkan keterangan diatas bahwasanya MI Ma'arif Darussalam Plaosan peran guru dalam menanamkan karakter toleransi yaitu, guru menjadi teladan bagi siswa agar memiliki karakter yang baik terutama dalam bersikap (baik sikap sosialisasi \& toleransi) baik dalam kelas maupun diluar kelas.

\section{Peran Guru Dalam Membimbing Karakter Toleransi Siswa}

Di MI Ma'arif Darussalam Plaosan bahwasanya peran guru dalam membimbing sikap toleransi siswa yaitu dengan cara mengarahkan kepada siswa bagaimana cara bersikap toleransi kepada satu sama lain. Selain itu juga memasukkannya dalam pembelajaran sehari-hari, sehingga siswa mudah memahami dan bisa ikut serta mengimplementasikanya. Kemudian juga cara yang dilakukan oleh guru yaitu memberi tahu apa sebab dan akibat jika di dalam sebuah lingkungan tidak ada sikap toleransi antar sesama, dengan tujuan siswa siswi mengetahui dampak negatif dari sikap intoleran. Dalam pembimbingan ini sendiri tentunya guru selalu memberikan contohcontoh sikap toleransi yaitu dengan menerapkan aturan yang telah dibuat, memberikan motivasi atau nasehat kepada siswa untuk saling menghargai dan menghormati serta harus selalu semangat untuk terus mengajarkan dan memberi contoh yang baik kepada siswa. Selanjutnta dalam membimbing didalam kelas guru memberikan contoh melakukan sikap berdoa dengan baik dan benar saat sebelum dan sesudah belajar, contoh lain saat melakukan diskusi dalam pembelajaran, guru memberikan kesempatan kepada siswa-siswi untuk bertanya dan memberikan pendapatnya. Kemudian selalu bersikap adil ke semua siswa-siswi dan memberikan teguran jika ada siswa yang melakukan kesalahan. Hal-hal yang seperti inilah yang selalu diajarkan oleh guru di MI Ma'arif Plaosan dalam membimbing siswa agar selalu memahami dan memaknai arti dari sikap toleransi yang baik.

Peran guru yang baik kinerja dan memiliki kepribadian yang baik, yaitu menjadi sorotan masyarakat sebagai figur teladan bagi anaknya dalam mendidik dan mengarahkan kepribadian anak menjadi lebih baik. Dalam membentuk kepribadian peserta didik tentunya seorang guru terlibat secara aktif membiasakan, mengarahkan dan membimbing dalam membentuk karakter toleransi. Peran guru orang tua sebagai teladan untuk membimbing peserta didiknya dalam pengembangan karakter toleransi ditunjukkan melalui cara memberikan contoh mulai dari bersikap, berbuat, bertutur kata, selalu bersikap toleransi baik dengan siswa atau dengan guru lainya sehingga siswa/ siswi bisa mencontoh karakter guru. Kemudian peran guru sebagai figur yang memberikan teladan baik kepada siswa menjadi sebuah keharusan, mengingat pendidikan bukan hanya menyampaikan ilmu pengetahuan, akan tetapi juga mendidik dan membimbing karakter anak menjadi lebih baik (Ramdan \& Fauziah, 2019, 109)

Berdasarkan keterangan diatas, MI Ma'arif Plaosan peran guru dalam membimbing siswa dalam membimbing toleransi siswa yaitu, dengan mengarahkan siswa tentang bagaimana bisa bersikap toleransi yaitu dengan memberikan informasi apa saja dampak negatif dari intoleran terutama sesame teman. Kemudian dalam membimbing guru menjadi teladan bagi siswa dengan selalu bersikap adil kepada siswa dan selalu menghargai pendapat siswa dalam proses pembelajaran sehingga siswa bisa meniru hal-hal yang dilakukan oleh guru.

\section{Peran Guru Dalam Mengidentifikasi Nilai Karakter Toleransi Dalam Pembelajaran PKn}

Di MI Ma'arif Darussalam Plaosan bahwasanya guru mengajarkan materi tentang Khebinekaan kepada siswa dalam proses pembelajaran pelajaran PKN. Yang mana tujuan dari materi ini yaitu untuk menanamkan dan memberi pengalaman secara 
langsung kepada setiap peserta didik dapat saling melihat dan menyimak teman yang sedang memberikan penjelasan dengan memiliki kesempatan yang sama untuk dapat terlihat oleh teman lain sehingga menghindari diskriminasi antar satu peserta didik dengan peserta didik lainya. Dengan demikianlah disini guru selalu menanamkan materi Kebhinekaan ini agar peserta didik memiliki peran penting untuk merawat Kebhinekaan Bangsa Indonesia dengan menumbuhkan kesadaran tentang keberagaman bagi setiap peserta didik sejak usia dini.

Materi pembelajaran yang diterapkan melalui proses pembelajaran Pkn di MI Ma'ariif Darussalam yaitu, menerapkan sikap-sikap yang sesuai dengan nilai-nilai yang terkandung dalam Sila Pancasila secara tepat, selanjutnya menerima dan menerapkan sikap toleransi terhadap keberagaman sosial yang berada dilingkungan sekolah maupun dilingkungan masyarakat agar siswa bisa memahami dan menerapkan indahnya perbedaan anatara yang satu dengan lainya. Kemudian dalam penilaian siswa yang dilakukan oleh guru yaitu dengan melihat pedoman pengamatan sikap yang ada di Rencana Pelkasanaan Pembelajaran (RPP). Penilaian sikap yang diamati guru yaitu apakah sudah baik atau belum. Caranya yaitu dengan pengamatan, jika terdapat siswa yang membuat kesalahan, guru harus memberikan teguran dan nasihat kepada siswa tersebut. Penilaian pada sikap, dan hasil belajar siswa berupa portofolio

Pembelajaran yang aktif dan efektif seharusnya terjadi pada semua mata pelajaran termasuk mata pelajaran Pendidikan Kewarganegaraan di sekolah dasar. Pembelajaran PPKn diupayakan agar mampu mempersiapkan siswa memiliki kepribadian yang baik. Pendidikan Kewarganegaraan membantu siswa dalam memiliki sikap menghormati dan tenggang rasa terhadap sesama, karena pada pembelajaran Pendidikan Kewarganegaraan diberikan nilai-nilai bagaimana bertingkah laku yang baik yang sesuai dengan Pancasila serta nilai karakter yang baik (Claudia et al., 2020; Muhamad Nova, 2017;Sirnayatin, 2017).Pendidikan karakter merupakan pendidikan yang mengembangkan nilai budaya dan karakter pada siswa, sehingga siswa dapat menerapkan nilai karakter tersebut dalam kehidupan sehari-hari. Pada hakikatnya pembelajaran Pendidikan Kewarganegaraan mengajarkan hidup di dalam kebhinekaan, salah satu nilai karakter yang tidak bisa berlangsung di dalam kegiatan pembelajaran yang mengajarkan kebhinekaan adalah nilai torelasi (Puniatmaja dan Renda 2021, 411).

Berdasarkan keterangan diatas bahwasanya MI Ma'arif Plaosan dalam mengidentifikasi nilai karakter toleransi dengan memberikan materi Kebhinekaan dengan tujuan agar siswa mengetahui dan memaknai arti perbedaan khususnya sesama teman sekolahnya. Dalam proses pembelajaran ini juga ada penilaian tersendiri bagi guru yang sudah dikemas dalam rencana pelaksanaan pembelajaran untuk melihat perkembangan sikap toleransi siswa selama proses pembelajaran maupun dilingkungan sekolahnya.

\section{Faktor Pendukung Dan Penghambat Dalam Penanaman Karakter Toleransi Siswa}

Faktor pendukung yang dilakukan oleh guru dalam penanaman karakter toleransi siswa di MI Ma'arif Darussalam Plaosan yaitu tersedianya fasilitas sekolah baik sarana maupun prasarana seperti media buku dan lain sebagainya sehingga bisa membantu guru untuk dijadikan media pembelajaran, kemudian terciptanya lingkungan yang kondusif dan adanya dorongan dari kepala sekolah untuk membentuk karakter toleransi. adanya motivasi dari semua guru untuk selalu menerapkan sikap saling terbuka dan bertoleransi yang sesyai dengan tartib serta visi misi sekolah yang ada, kemudian selalu menanamkan nilai-nilai religius dan membina karakter dengan pembiasaan.

Kemudian yang menjadi faktor penghambat yaitu kurangnya daya tangkap anak berbeda-beda, hal ini menjadikan hambatan dalam membentuk karakter toleransi pada 
siswa adalah daya tangkap setiap anak yang berbeda-beda. Kurangnya kesadaran siswa akan peraturan sekolah, padahal kepala seolah dan guru telah memberi contoh akan tetapi masih ada beberapa siswa yang belum sadar untuk melaksanakannya dengan baik. terdapat beberapa siswa yang kurang memahami sikap tolerasi, seperti dalam hal bersosialisasi dengan teman-teman sebayanya kurang bagus, kurang bisa menerima pendapat teman, serta tidak mudah beradaptasi dengan lingkungannya.

Faktor-faktor yang mempengaruhi toleransi yang pertama adalah agama dan norma sosial pengaruh norma sosiald an agama bisa menjadi signifikan, jika norma sosial dan agama dapat dikembangkan secara positif maka berperan lebih besar dalam membangun toleransi etnis. Faktor selanjutnya adalah pengasuhan orang tua dan guru. Faktor penentu untuk nilai toleransi tumbuh pada anak usia dini adalah pendidikan melalui pengasuhan orang tua dan guru. Faktor yang mempengaruhi toleransi lainnya yaitu pendidikan. Berdasarkan hasil penelitian ditemukan bahwa terdapat pengaruh positif dan signifikan dari praktik pendidikan terhadap sikap siswa dalam nilai toleransi. Prinsip kerukunan yang dipegang teguh, prinsip hormat dan solidaritas yang tinggi antara sesama juga menjadi faktor pendorong pada toleransi. Berdasarkan hasil penelitian ditemukan beberapa faktor penyebab terjadinya intoleransi salah satunya dalam kebebasan beragama antara lain yaitu, berbeda pendapat tentang kepercayaan, berselisih dengan etnis lain dengan membawa-bawa agama masingmasing, berselisih karena masalah pribadi dengan membawa-bawa agama, merasa terganggu dengan kegiatan keagamaan yang diselenggarakan disekitar lingkungan permukiman (Pitaloka et al., 2021, 1700)

Berdasarkan keterangan diatas yang menjadi faktor pendukung dalam penerapan karakter toleransi di MI Ma'arif Darussalam Plaosan yaitu, sudah tersedianya fasilitas media pembelajaran seperti modul, buku untuk pembelajaran tentang materi toleransi yang terdapat dalam materi pembelajaran kewarganegaraan, kemudian terdapat lingkungan yang kodusif serta adanya dorongan dari kepala sekolah dan motivasi dari guru agar selalu bersikap toleransi ketika berada dilingkungan sekolah. Kemudian faktor penghambatnya yaitu masih ditemukan anak yang daya tangkapnya berbeda, tentunya ini menjadi hambatan dalam membentuk karakter toleransi pada siswa, selanjutnya masih adanya kekurangan kesadaran siswa yang belum sepenuhnya melaksanakan karakter toleransi itu sendiri. MI Ma'arif Darussalam Plaosan peran guru dalam menanamkan karakter toleransi yaitu, guru menjadi teladan bagi siswa agar memiliki karakter yang baik terutama dalam bersikap (baik sikap sosialisasi \& toleransi).

\section{KESIMPULAN DAN SARAN}

Berdasarkan dari hasil penelitian ini dapat disimpulkan bahwasanya, MI Ma'arif Plaosan Darussalam Plaosan sudah menerapkan karakter toleransi, Adapun bentuk karakter toleransi yaitu, tidak menghina teman yang berbeda suku/ ras, selalu menghargai perbedaan pendapat teman,mentaati peraturan sekolah dan lain sebagainya yang bertujuan untuk membentuk kepribadian anak dan menjaga kekeluargaan satu sama lainya. MI Ma'arif Darussalam Plaosan peran guru dalam menanamkan karakter toleransi yaitu, guru menjadi teladan bagi siswa agar memiliki karakter yang baik terutama dalam bersikap (baik sikap sosialisasi \& toleransi) baik dalam kelas maupun diluar kelas. MI Ma'arif Plaosan peran guru dalam membimbing siswa dalam membimbing toleransi siswa yaitu, dengan mengarahkan siswa tentang bagaimana bisa bersikap toleransi yaitu dengan memberikan informasi apa saja dampak negatif dari intoleran terutama sesame teman. MI Ma'arif Plaosan dalam mengidentifikasi nilai karakter toleransi dengan memberikan materi Kebhinekaan dengan tujuan agar siswa mengetahui dan memaknai arti perbedaan khususnya sesama 
teman sekolahnya. Dalam proses pembelajaran ini juga ada penilaian tersendiri bagi guru yang sudah dikemas dalam rencana pelaksanaan pembelajaran untuk melihat perkembangan sikap toleransi siswa selama proses pembelajaran maupun dilingkungan sekolahnya. faktor pendukung dalam penerapan karakter toleransi di MI Ma'arif Darussalam Plaosan yaitu, sudah tersedianya fasilitas media pembelajaran seperti modul, buku untuk pembelajaran tentang materi toleransi yang terdapat dalam materi pembelajaran kewarganegaraan, kemudian terdapat lingkungan yang kodusif serta adanya dorongan dari kepala sekolah dan motivasi dari guru agar selalu bersikap toleransi ketika berada dilingkungan sekolah. Kemudian faktor penghambatnya yaitu masih ditemukan anak yang daya tangkapnya berbeda, tentunya ini menjadi hambatan dalam membentuk karakter toleransi pada siswa, selanjutnya masih adanya kekurangan kesadaran siswa yang belum sepenuhnya melaksanakan karakter toleransi itu sendiri

\section{UCAPAN TERIMAKASIH}

Alhamdulillahirabilalamin, puji syukur penulis panjatkan ke hadirat Allah SWT atas segala rahmat dan karunia-Nya sehingga proses penyusunan artikel ini dapat diselesaikan. Penulis juga berterimakasih kepada pihak-pihak yang turut serta mendukung kelanjaran dalam penyusunan ini, tak lupa penulis sampaikan terimakasih kepada MI Ma'arif Darussalam Plaosan Yogyakarta yang sudah turut serta dalam memberikan informasi penelitian.

\section{REFERENSI}

Afifah, N. (2019). Efektivitas Media Ajar untuk Siswa Kelas Rendah Berbasis Nilai Karakter Toleransi terhadap Sesama dengan Berbantu Aplikasi Sparkol Videoscribe. Modeling: Jurnal Program Studi PGMI, 6(2).

Ariyanti, F., Dwi Setya Putri, A., Guru Sekolah Dasar, P., \& Ilmu Pendidikan, F. (2019).

Chaira. 2021. "Peran Guru Kelas Dalam Penanaman Nilai Karakter Toleransi Siswa Kelas IV Di Sekolah Dasar Negeri Kembangan Utara 05 Pagi." Dinamika Sekolah Dasar 10.

Claudia, C., Prabawati, H., Malihah, M., Novrezi, M., Sahara, S., \& Safitri, D. (2020). Pelatihan Pendidikan Karakter pada Anak Pekerja di Yayaysan Swara Peduli Indonesia Jakarta. Jurnal Penelitian Dan Pengabdian Kepada Masyarakat, 8(1).

Hidayati, A. N. (2021). Peran Pendidikan Kepramukaan sebagai Media Pembentukan Karakter Kepemimpinan Siswa Sekolah Dasar. Jurnal Riset Madrasah Ibtidaiyah (JURMIA), 1(1), 11-20.

Haryati, Sri. (2017). Pendidikan Karakter dalam Kurikulum 2013:

Hasibuan, H. A. (2021). Pendidikan Kewarganegaraan: Internalisasi Nilai Toleransi Untuk Mencegah Tindakan Diskriminatif Dalam Kerangka Multikultural. In Jurnal Pendidikan Kewarganegaraan Undiksha (Vol. 9, Issue 2).

Insani, G. N., Dewi, D., \& Furnamasari, Y. F. (n.d.). Integrasi Pendidikan Karakter dalam Pembelajaran Pendidikan Kewarganegaraan untuk Mengembangkan Karakter Siswa Sekolah Dasar.

Karmila, Nita, dan Rini Sri Indriani. 2019. “Nilai-Nilai Pendidikan Karakter Pada Materi Ajar Pendidikan Lingkungan Hidup Untuk Sekolah Dasar/ Madrasah Ibtidaiyah Kelas Ii." Jurnal Pendidikan Dan Pengajaran Guru Sekolah Dasar (Jppguseda) 2 (1): 26-29.

Nurjannah, Nurjannah. 2019. "Analisis Nilai Karakter Pada Kelas V Sd Negeri Paya Peunaga Mata Pelajaran Pkn." Bina Gogik: Jurnal Ilmiah Pendidikan Guru Sekolah Dasar 6 (2). 
Nurohmah, A. N., \& Dewi, D. A. (2021). Penanaman Nilai Moral dan Karakter di Era Pandemi melalui Pendidikan dengan Mengimplementasikan Nilai-Nilai Pancasila. Journal of Education, Psychology and Counseling, 3(1), 119-128.

Pertiwi, Amalia Dwi, Siti Aisyah Nurfatimah, Dinie Anggraeni Dewi, dan Yayang Furi Furnamasari. 2021. "Implementasi Nilai Pendidikan Karakter Dalam Mata Pelajaran PKn di Sekolah Dasar.” Jurnal Basicedu 5 (5): 4328-33.

Pitaloka, D. L., Dimyati, D., \& Purwanta, E. (2021). Peran Guru dalam Menanamkan Nilai Toleransi pada Anak Usia Dini di Indonesia. Jurnal Obsesi : Jurnal Pendidikan Anak Usia Dini, 5(2), 1696-1705.

Puniatmaja, I. Gede Pait Budhi, dan Ndara Tanggu Renda. 2021. "Modul Pembelajaran PPKn Bermuatan Nilai Karakter Toleransi Pada Kelas V Sekolah Dasar.” Jurnal Pedagogi Dan Pembelajaran 4 (3): 409-19.

Rahmawati, M., \& Harmanto. (2020). Pembentukan Nilai Karakter Toleransi dalam Pembelajaran Pendidikan Pancasila dan Kewarganegaraan Bagi Siswa Tunagrahita. Journal of Civics and Moral Studies, 5(1), 59-72.

Ramadhaniar, N., Hidayat, T., \& Taufiq, M. (2020). Harmoni Pengetahuan Dan Sikap Toleransi Pada Pembelajaran Pendidikan Kewarganegaraan Di Sdi Saroja Surabaya (Vol. 7, Issue 2).

Ramdan, A. Y., \& Fauziah, P. Y. (2019). Peran orang tua dan guru dalam mengembangkan nilai-nilai karakter anak usia sekolah dasar. Premiere Educandum : Jurnal Pendidikan Dasar Dan Pembelajaran, 9(2), 100.

Romadhan, S. (2021). Pengembangan Bahan Ajar Budaya Literasi Melalui Cerita Rakyat dalam Membentuk Sikap Nasionalisme Siswa Sekolah Dasar. Jurnal Riset Madrasah Ibtidaiyah (JURMIA), 1(1), 81-88.

Suttrisno, S. (2021). PENGARUH PEMANFAATAN ALAT PERAGA IPS TERHADAP KINERJA GURU SEKOLAH DASAR. Jurnal Ilmiah Pendidikan Dasar, 8(1), 77-90.

Setiawan, A. R. (2020). Pembelajaran Tematik Berorientasi Literasi Saintifik. Jurnal Basicedu, 3(2), 524- 532.

Zaenuri, Z., \& Prastowo, A. (2021). Peran Guru Dalam Perencanaan Pembelajaran Berbasis Aplikasi Zoom Meeting Di Sekolah Dasar. Edukatif: Jurnal Ilmu Pendidikan, 3(4), 1734-1744.

Zubaidah, Siti. (2015). Implementasi pendidikan karakter dalam pendidikan agama islam di sd gayamsari 02 semarang. Skripsi. Semarang: Universitas Islam Negeri Walisongo. 